\title{
Analisis Kelayakan Usaha Tahu Mandiri Desa Kotangan Kecamatan Galang Kabupaten Deli Serdang
}

\author{
Feasibility Analysis of Independent Tofu Business in \\ Kotangan Village, Galang District, Deli Serdang Regency
}

\author{
Muhammad Deaprama Aydra, Retna Astuti Kuswardani* \& Mitra Musika Lubis
}

Program Studi Agribisnis, Fakultas Pertanian, Universitas Medan Area, Indonesia

\begin{abstract}
Abstrak
Tujuan penelitian ini adalah menganalisis kelayakan dari aspek finansial dan non finansial Usaha Tahu Mandiri. Metode analisis data yang digunakan adalah kualitatif (aspek hukum, lingkungan, pasar dan pemasaran, teknis dan manajemen dan sumber daya manusia) dan kuantitatif untuk menganalisis aspek finansial melalui empat kriteria investasi, yaitu NPV, IRR, Net B/C, payback period.Aspek non finansialaspek hukum belum layak karena izin kepemilikkan tanah Usaha hanya memiliki Surat Penyerahan Penguasaan Tanah Dengan Cara Ganti Rugi.aspek manajemen kurang layak karena usaha ini belum memiliki pencatatan finansial yang baik dan belum memiliki struktur organisasi.Aspek lingkungan kurang layak karena membuang air limbahnya langsung ke kali terdekat tanpa perlakukan khusus.Analisis finansial digunakan Nilai NPV diperoleh sebesar Rp 109.897,985, Net B/C sebesar 2,02, IRR sebesar 49,26\%, dan payback period selama tiga tahun sepuluh bulan sebelas hari pada investasi pertama dan Nilai NPV diperoleh sebesar Rp 66.127,532, Net B/C sebesar 1,25, IRR sebesar 34,06\%, dan payback period selama dua tahun sepuluh bulan tigabelas hari pada investasi kedua. Aspek finansialmaupun non finansial menyatakan Usaha Tahu Mandiri layak untuk dijalankan kecuali pada aspek hukum, manajemen dan lingkungan.

Kata Kunci: Kelayakan, Usaha Tahu, Finansial, Non Finansial
\end{abstract}

\begin{abstract}
The purpose of this study is to analyze the feasibility of the financial and non-financial aspects of Mandiri tofu business. Data analysis methods used are qualitative (legal, environmental, market and marketing, technical and management and human resource aspects) and quantitative to analyze financial aspects through four investment criteria, namely NPV, IRR, Net B / C, payback period. Non-financial aspects of the legal aspect are unfeasible because the Business Ownership Permit only has a Letter of Submission of Land Tenure by Compensation. The management aspect isn't feasible because this business doesn't yet have a good financial record and doesn't have an organizational structure. Environmental aspects aren't feasible because it discharges its wastewater directly to the nearest river without special treatment. The financial analysis used NPV value obtained at Rp 109,897,985, Net B / C at 2.02, IRR at $49.26 \%$, and payback period for three years and ten months eleven days on the first investment and NPV value obtained at Rp 66,127,532, Net B / C is 1.25, IRR is 34.06\%, and the payback period is two years ten months and thirteen days on the second investment. Financial and non-financial aspects state Mandiri tofu business is feasible to except in legal, management, and environmental aspects.
\end{abstract}

Keywords: Feasibility, Tofu Business, Financial, Non-Financial

How to Cite: Aydra, M.D., Kuswandani, R.A. \& Lubis, M.M., (2020). Analisis Kelayakan Usaha Tahu Mandiri Desa Kotangan Kecamatan Galang Kabupaten Deli Serdang. Jurnal Ilmiah Pertanian (JIPERTA), 2 (1): 98-108.

*E-mail: retnaastuti@uma.ac.id ISSN 2550-1305 (Online)

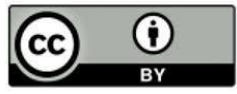




\section{PENDAHULUAN}

Pada dasarnya kegiatan agroindustri adalah meningkatkan kemampuan pelaku agribisnis dalam meningkatkan pendapatan, menyerap tenaga kerja lebih banyak, mampu memberikan dampak positif terhadap sektor lain dan memberikan nilai tambah dari proses tersebut, karena dengan hal ini sektor pertanian dapat memperpanjang siklus usaha, menghasilkan produk sekunder yang bermutu, sehingga pihak yang terlibat yaitu petani dan pelaku agroindustri memperoleh nilai tambah. Dengan kata lain nilai tambah merupakan balas jasa dari alokasi tenaga kerja dan keuntungan pelaku agroindustri. Dalam perusahaan skala rumah tangga, pemilik bertindak apa saja; mulai dari pembelian bahan baku, pengolahan bahkan sampai penjualan hasil agroindustri tersebut, karena dalam agroindustri skala rumah tangga tidak jelas pembagian tugas (Soekartawi, 2001)

Industri kecil yang mengolah hasil-hasil pertanian (agroindustri) tahan terhadap dampak krisis ekonomi bersifat padat karya merupakan salah satu alternatif dalam membangun kembali perekonomian Indonesia saat ini (Anoraga \& Sudantoko, 2002). Selain dapat menciptakan lapangan kerja bagi masyarakat sekitar perusahaan, juga dapat menciptakan nilai tambah bagi produk pertanian khususnya pangan. Salah satu industri kecil yang potensial untuk dikembangkan adalah pabrik pembuatan tahu, Menurut (Sholikhah, 2017; Anzhita, 2019)Peran industri kecil tahu terhadap kondisi sosial ekonomi masyarakat yang meliputi, menciptakan lapangan pekerjaan dan dapat menyerap banyak tenaga kerja, pendapatan masyarakat meningkat setelah menjadi pengrajin tahu, tingkat pendidikan masyarakat meningkat karena terjadinya peningkatan pendapatan menyebabkan masyarakat mampu menyekolahkan anakanaknya ke jenjang yang lebih tinggi. hal ini terjadi karena konsumen tahu sangat luas, mencakup semua strata sosial. Tahu tidak hanya dikonsumsi oleh masyarakat kelas bawahdan menengah saja, akan tetapi juga kelas atas.

Kabupaten Deli Serdang terdiri dari 22 kecamatan. Pada tabel 1dapat dilihat bahwa perajin tahu hanya ditemukan di enam kecamatan. Perajin tahu terbanyak pada tahun 2016 terdapat di Kecamatan Lubuk Pakam dan Kecamatan Beringin dengan tiga perajin tahu. Pada tahun 2017 terdapat penambahan empat perajin tahu yaitu dua perajin di Kecamatan Lubuk Pakam, satu perajin di Kecamatan Galang dan satu perajin di Kecamatan Pagar Merbau, sehingga jumlah perajin tahu di Kecamatan Galang sama dengan Kecamatan Beringin.

Ada 3 industri yang memproduksi tahu di Kecamatan Galang yang terdaftar di Dinas Perindustrian dan masih ada juga industri tahu yang belum terdaftar di Dinas Perindustrian tetapi berdasarkan prasurvey penulis secara fisik sama besar dengan yang sudah terdaftar di Dinas, baik dari bangunan, skala produksi, banyak pekerja. Salah satu industri tahu yang belum terdaftar di Dinas Perindustrian dan tanpa menggunakan bahan pengawet adalah Usaha Tahu Mandiri milik bapak Suprianto 
Muhammad Deaprama Aydra Ozi, Retna Astuti K \& Mitra Musika Lubis, Analisis Kelayakan Usaha Tahu Mandiri Desa Kotangan Kecamatan Galang Kabupaten Deli Serdang

Tabel 1.Perkembangan Perajin Tahu di Kabupaten Deli Serdang

\begin{tabular}{|c|c|c|c|c|c|c|}
\hline \multicolumn{4}{|c|}{2016} & \multicolumn{3}{|c|}{2017} \\
\hline \multirow{2}{*}{ No } & \multirow{2}{*}{$\begin{array}{l}\text { Nama } \\
\text { Perajin }\end{array}$} & \multicolumn{2}{|c|}{ Alamat } & \multirow{2}{*}{ Nama Perajin } & \multicolumn{2}{|l|}{ Alamat } \\
\hline & & Desa & Kecamatan & & Desa & Kecamatan \\
\hline 1 & Yatiman & Paluh Kemiri & Lubuk Pakam & Yatiman & Paluh Kemiri & Lubuk Pakam \\
\hline 2 & Suratni & & Lubuk Pakam & Suratni & & Lubuk Pakam \\
\hline 3 & Kok Dijan & & Lubuk Pakam & Kok Dijan & & Lubuk Pakam \\
\hline 4 & Mustafa & Karang Anyar & Beringin & Mustafa & Karang Anyar & Beringin \\
\hline 5 & Sumarlan & Karang Anyar & Beringin & Sumarlan & Karang Anyar & Beringin \\
\hline 6 & $\begin{array}{l}\text { Kasiman } \\
\text { Samsul }\end{array}$ & Karang Anyar & Beringin & Kasiman & Karang Anyar & Beringin \\
\hline 7 & Bahri & Purwodadi & Pagar Merbau & Samsul Bahri & Purwodadi & Pagar Merbau \\
\hline 8 & Supomo & Payagambar & Galang & Supomo & Payagambar & Galang \\
\hline 9 & Jemirin & Timbang Deli & Galang & Jemirin & Timbang Deli & Galang \\
\hline 10 & Sopan & Bangun Sari & Tanjung Morawa & Sopan & Bangun Sari & Tanjung Morawa \\
\hline 11 & Bak Cai & Bandar Klippa & Percut Sei Tuan & Bak Cai & Bandar Klippa & Percut Sei Tuan \\
\hline 12 & Mukiman & Sambirejo & Percut Sei Tuan & Mukiman & Sambirejo & Percut Sei Tuan \\
\hline 13 & - & - & - & Pasran & Bakaran Batu & Lubuk Pakam \\
\hline 14 & - & - & - & Siswati & Bakaran Batu & Lubuk Pakam \\
\hline 15 & - & - & - & Pak Sudi & Pasar Miring & Pagar Merbau \\
\hline 16 & - & - & - & Gito & Timbang Deli & Galang \\
\hline
\end{tabular}

Sumber: Dinas Perindustrian dan Perdagangan Kabupaten Deli Serdang

Menurut (Kasmir \& Jakfar, 2003) studi kelayakan binis dilakukan untuk mengidentifikasikan masalah di masa yang akandatang, sehingga dapat menimbulkan kemungkinan melesetnya hasil yang ingin dicapai dalam suatu investasi. Mengingat usaha tahu mandiri milik Bapak Suprianto yang terletak di Desa Kotangan Kecamatan Galang Kabupaten Deli Serdang sudah berdiri selama 10 tahun mulai dari tahun 2008 belum pernah melakukan studi kelayakan untuk usahanya maka penulis tertarik melakukan penelitian yang berjudul "Analisis Kelayakan Usaha Tahu Mandiri Desa Kotangan Kecamatan Galang Kabupaten Deli Serdang”.

\section{METODE PENELITIAN}

Penelitian dilakukan pada usaha tahu Mandiri milik bapak Suprianto yang terletak di Desa Kotangan Kecamatan Galang Kabupaten Deli Serdang.penentuan tersebut dilakukan dengan menggunakan teknik purposive sampling (secara sengaja) dengan kriteria sampel (1) Sudah berdiri 10 tahun, (2) Hanya satu - satunya industri tahu didesa tersebut, (3) Belum terdaftar di Dinas Perindustrian. Penelitian ini menggunakan data primer maupun data sekunder, baik yang bersifat kualitatif maupun kuantitatif.Data primer diperoleh dengan melakukan wawancara langsung dengan menggunakan kuesioner, konsultasi, dan pengamatan langsung.Responden yang menjadi sumber data primer yaitu pemilik dan karyawan.Data sekunder diperoleh dari data internal usaha tahu maupun diperoleh dari instansi-instansi yang terkait dengan penelitian ini.Data dan informasi yang telah dikumpulkan dianalisis secara kualitatif dan kuantitatif dan diolah dengan menggunakan bantuan komputer atau laptop, yakni program Microsoft Excel 2007. Analisis kualitatif dilakukan dengan menganalisis aspek hukum, aspek lingkungan, aspek pasar, aspek teknis, aspek manajemen dan sumber daya manusia. Analisis 
kualitatif dilakukan untuk mengetahui apakah usaha tersebut layak atau tidak secara non finansial, sedangkan analisis kuantitatif dilakukan untuk mengetahui apakah usaha tersebut layak ditinjau dari aspek finansial dengan empat criteria investasi, yaitu analisis nilai bersih sekarang ( Net Present Value / NPV), tingkat pengembalian investasi (Internal Rate of Return / IRR), masa pengembalian invests (Payback Period), rasio manfaat bersih dan biaya (Net Benefit and Cost Ratio/Net B/C Ratio).

\section{HASIL DAN PEMBAHASAN Aspek Hukum}

Menurut (Suliyanto, 2010) Ketentuan hukum untuk setiap jenis usaha berbeda beda, tergantung pada kompleksitas bisnis tersebut. Adanya otonomi daerah menyebabkan ketentuan hukum dan perizinan antara daerah yang satu dengan daerah yang lain berbeda - beda. Oleh karna itu, pemahaman mengenai ketentuan hukum dan perizinan investasi untuk setiap daerah merupakan hal yang sangat penting untuk melakukan analisis kelayakan aspek hukum. Ketentuan hukum dan perizinan daerah Deli Serdang Peraturan Menteri Perdagangan Republik Indonesia Nomor: 36/MDag/Per/9/2007 Tentang Penerbitan Surat Izin Usaha Perdagangan pasal 3 ayat 1 dan pasal 4 ayat 1 . Usaha Tahu Mandiri memiliki bentuk badan hukum perseorangan hal tersebut dipilih agar pemilik usaha dapat dengan sepenuhnya mengambil keputusan baik finansial maupun non finansial secara cepat.Terkait dengan peraturan perundang undangan, tidak ada peraturan atau izin yang diperlukan untuk mendirikan usaha perseorangan, pemilik cukup mendapat izin dari pemerintah setempat, terbukti dengan adanya Surat Izin Usaha Mikro dan Kecil No.118/IUMK/CMT.GALANG/XI/2016 dari Pemerintah Kabupaten Deli Serdang Kecamatan Galang.

Usaha Tahu Mandiri belum pernah melakukan pembayaran pajak pendapatan hal itu dikarenakan pemilik Usaha Tahu Mandiri belum memiliki Nomor Pokok Wajib Pajak (NPWP). Jika dilihat dari aspek hukum surat kepemilikan tanah yang dimiliki Usaha Tahu Mandiri berkekuatan hukum sangat rendah hal tersebut dikarenakan status tanah dimana usaha tersebut berdiri hanya Surat Penyerahan Penguasaan Atas Tanah Dengan Cara Ganti Rugi. Usaha pembuatan tahu ini telah didirikan sejak tahun 2008 dan berpindah lokasi pada tahun 2014 namun pendirian tidak menyertakan Surat Izin Mendirikan Bangunan (SIMB).

\section{Aspek Lingkungan}

Usaha Tahu Mandiri memiliki dua limbah produksi, yaitu limbah padat dan cair akibat perebusan dan proses produksi tahu.Yang pertama limbah padat ampas tahu hasil produksi dimanfaatkan kembali oleh pemilik yaitu dengan menjual kepada peternak di sekitar lokasi usaha. Yang kedua limbah cair sisa proses produksi, limbah air ini dialirkan kesungai kecil terdekat melalui saluran pipa yang ditanam dan dihubungkan langsung kebadan sungai tanpa perlakuan khusus terlebih dahulu. Menurut (Irwanto, 2011)Dampak pembuangan limbah cair industri tahu bagi penduduk yang mengkonsumsi air sumur yang tercemar limbah tahu yaitu bisa menimbulkan berbagai macam penyakit, hal ini bisa disebabkan oleh karena pH, COD, dan BOD air limbah tahu 
yang melebihi ambang batas dari standar baku mutu air limbah.Menurut Peraturan Menteri Lingkungan Hidup Republik Indonesia No. 5 Tahun 2014 Lampiran XVIII Tentang Baku Mutu Air Limbah, ditetapkan bahwa air limbah pabrik boleh dibuang ke sungai atau lingkungan jika $\mathrm{pH}$ air limbah tersebut berkisar 6 - 9, nilai BOD kurang dari $150 \mathrm{mg} / \mathrm{l}$ dan nilai COD kurang dari $300 \mathrm{mg} / \mathrm{l}$. Hasil pengujian air sungai tempat pembuangan limbah cair Usaha Tahu Mandiri menunjukkan bahwa $\mathrm{pH}$ air sungai 6,62 dan nilai BOD dan COD yang diperoleh adalah $26,00 \mathrm{mg} / \mathrm{l}$ dan $81,25 \mathrm{mg} / \mathrm{l}$, sehingga hasil pengujian air sungai tempat pembuangan limbah cair Usaha Tahu Mandiri menunjukkan bahwa air sungai masih dikatakan aman.Untuk meminimalisir gangguan yang ditimbulkan akibat air limbah cair sisa kegiatan produksi sebaiknya pemilik tidak secara langsung mengalirkan air limbah kebadan sungai karena air limbah tersebut dapat merusak ekosistem sungai. Untuk kegiatan Usaha Tahu Mandiri belum memiliki surat izin Analisis Dampak Lingkungan (AMDAL).

\section{Aspek Pasar dan Pemasaran}

Aspek pasar yang diteliti meliputi bauran pemasaran.pengertian bauran pemasaran adalah kombinasi dari variabel atau kegiatan yang merupakan inti dari sistem pemasaran yaitu produk, harga, promosi, dan distribusi.(Sumarni, Murti, \& Soeprihanto, 2010)

\section{a. Produk}

Produk yang dihasilkan Usaha Tahu Mandiri dibagi atas 2 (dua) yaitu berdasarkan proses dan berdasarkan bentuk. Tahu yang diproduksi berdasarkan proses dibagi menjadi 2 (dua) dua jenis berdasarkan proses produksinya, yaitu tahu putih dan tahu goreng. Sedangkan tahu yang diproduksi berdasarkan bentuk Usaha Tahu Mandiri hanya memproduksi 1 (satu) bentuk yaitu persegi empat.Untuk bahan penggumpal pada produk tahu putih menggunakan cuka dan bumbu rahasia lainnya.Produk sampingan yang dihasilkan adalah ampas tahu (limbah padat) yang dijual ke peternak sebagai makanan ternak.

\section{b. Harga}

Harga produk Usaha Tahu Mandiri berbeda-beda sesuai dengan jenis tahu yang dihasilkan.Penentuan harga yang ditentukan untuk tahu putih Rp. 33.000/kotak dengan isi sebanyak 121 potong. Untuk harga jual tahu goreng ada tiga ukuran yaitu besar, sedang dan kecil dangan harga jual tahu goreng ukuran besar Rp. 800/potong, harga jual tahu goreng ukuran sedang Rp. 400/potong, dan harga tahu goreng ukuran kecil Rp. 200/potong. Sedangkan harga ampas tahunya adalah sebesar Rp 35.000,- per karung (ukuran 50kg).

\section{c. Promosi}

Usaha Tahu Mandiri tidak melakukan kegiatan promosi secara komersil namun pembeli mendapat informasi tentang tahu yang diproduksi oleh Usaha Tahu Mandiri dari mulut ke mulut. 


\section{d. Distribusi}

Produk Usaha Tahu Mandiri didistribusikan dengan beberapa cara antara lain:

$>$ Rata - rata konsumen datang lagsung ke pabrik Usaha Tahu Mandiri adalah 20 orang/hari.

> Rata - rata pedagang pengecer datang membeli ke pabrik Usaha Tahu Mandiri adalah 15 orang/hari yang kemudian disalurkan kembali ke konsumen.

$>$ Pedagang pengecer pasar desa datang ke pabrik Usaha Tahu Mandiri adalah 5 orang/hari yang kemudian dipasarkan ke konsumen di Desa Bangun Purba, Desa Tiga Juhar, dan Desa Kotarih Pekan.

$>$ Pedagang pasar kecamatan datang ke pabrik Usaha Tahu Mandiri adalah 3 orang/hariuntuk membeli tahu goreng yang selanjutnya dipasarkan ke konsumen di pasar Kecamatan Galang yaitu Pasar Patumbukan dan Pasar Galang.

\section{Aspek Teknis}

\section{a. Lokasi Usaha}

Lokasi Usaha Tahu Mandiri terletak di Dusun II Desa Kotangan Kecamatan Galang.Lokasi dipilih berdasarkan beberapa pertimbangan.Pertama, yaitu lokasi memiliki halaman yang luas. Hal ini dipertimbangkan untuk menaruh kepingan kayu bakar yang dipakai untuk proses produksi juga sebagai tempat parkir becak barang milik bapak Suprianto. Kedua, yaitu akses transportasi yang mudah dan memadai, lokasi pabrik berada didesa yang tidak jauh dari pusat keramaian sehingga akses keluar masuk pabrik cukup mudah.Ketiga, lokasi pabrik dianggap strategis karena terletak didaerah tidak padat penduduk.

\section{b. Bahan Baku}

Menurut (Fitriani, 2017) Bahan baku mempunyai pengaruh yang signifikan terhadap produksi. Bahan baku yang digunakan didalam proses produksi adalah kacang kedelai. Pengerajin usaha tahu menggunakan kedelai impor dalam proses produksinya. Hal ini dinilai karena dari segi kualitas kedalai impor memiliki kualitas yang lebih baik dibandingkan kedelai lokal.Kedalai impor tidak mengandung banyak kotoran. Dari segi ukuran kedelai impor memiliki ukuran bulir yang lebih besar dan sama rata sehingga lebih cepat mekar dalam proses perendaman. Usaha tahu mandiri memiliki satu toko langganan untuk membeli pasokan kedelai, Toko tersebut terlatak di Kota Galang.Usaha Tahu Mandiri memasok kedelai $\pm 1050 \mathrm{~kg}$ setiap minggunya dari toko langgananya tersebut.Hingga saat ini, pemilik Usaha Tahu Mandiri belum menemukan kesulitan yang berarti dalam memperoleh pasokan kedelai.

\section{c. Luas Produksi}

Usaha Tahu Mandiri yang diusahakan di Desa Kotangan masih tergolong usaha kecil.Pada saat ini, kapasitas produksi per hari berada pada kisaran $120 \mathrm{~kg}$ kedelai/hari. Sehingga dalam satu periode produksi mengahasilkan 2000 potong/hari untuk tahu 
goreng ukuran besar, 1.500 potong/hari untuk tahu goreng ukuran sedang, 200 potong/hari untuk ukuran kecil dan 11 kotak/hari untuk tahu putih.

\section{d. Siklus Produksi}

Siklus produksi yang dimiliki Usaha Tahu Mandiri cukup sederhana pada awal tahun berdirinya Usaha Tahu Mandiri hanya memproduksi satu jenis tahu. Ketika pada awalnnya berdirinya Usaha Tahu Mandiri tepatnya tahun 2008 produsen hanya memproduksi $20 \mathrm{~kg}$ kedalai yang menghasilkan 10 kotak tahu putih/hari. Pada tahun 2010 produksi Usaha Tahu Madiri mengalami peningkatan yaitu $38 \mathrm{~kg} / \mathrm{hari}$ dengan hasil produksi 28 kotak tahu putih/hari. Seiring dengan berjalannya tahun 2014 produksi Usaha Tahu Mandiri terus mengalami kenaikan, hingga pada tahun 2018 Usaha Tahu Mandiri mengolah $120 \mathrm{~kg} /$ hari kedelai dikarenakan penambahan jenis tahu yang diproduksi. Namun dengan penambahan jenis tersebut mengakibatkan perubahan jam kerja pada siklus produksi. Pada tahun 2008 hingga 2013 tahu putih diproduksi pada malam hari tepatnya pukul 10 dan akan dijual pada keesokan harinya. Biasanya para pedagang akan mengambil tahu yang sudah disiapkan dalam wadah kotak pada pukul 4 pagi. Pada tahun 2014 usaha tahu mandiri beralih memproduksi tahu goreng yang diproduksi pada pagi tepatnya pukul 5 dan akan diambil oleh pedangang pada sore atau malam hari untuk dijual keesokan harinya.

\section{e. Proses Produksi}

Secara umum proses produksi tahu hampir sama yaitu mulai dari perendaman kedelai hingga pencetakan, perlakuan pada akhir produksi yang membedakan tahu akan dijual dalam bentuk tertentu, ada yang menjual dalam bentuk tahu putih, tahu goreng dan sebagainya. Usaha Tahu Mandiri memilih untuk memproduksi tahu putih dan tahu goreng.tahapan dalam proses pembuatan tahu yang diproduksi Usaha Tahu Mandiri adalah perendaman, penggilingan, perebusan, penyaringan, penggumpalan, pencetakan, pemotongan dan penggorengan.

\section{f. Layout Usaha}

Menurut Wignjoesoebroto (1996) dalam (Syafa'at, 2016) Secara umum pola aliran bahan menggunakan tipe pocess layout dimana layout penataan fasilitas mengacu pada urutan proses produksi. Kegiatan Usaha Tahu Mandiri memiliki luas bangunan 6 x 18m untuk bangunan utama dan 4 x $5 \mathrm{~m}$ untuk gudang kayu.Selain bangunan pada pabrik ini terdapat halaman yang cukup luas. Desain interiordiatur sedemikian rupa agar mempermudah alur proses produksi. Ruang produksi dibagi menjadi beberapa bagian yaitu, gudang kayu, ruang penggorengan yang didalamnya meliputi satu buah meja beton untuk meletakkan lima buah kompor gas yang terlatak disisi utara, sebuah jendela untuk ventilasi, tiga buah rak untuk penirisan tahu yang sudah digoreng yang terletak disisi kiri kanan dan tengah ruangan, gudang penyimpanan bahan baku, ruang istirahat, ruang mesin, kamar mandi, dan satu tempat pengolahan yang didalamnya meliputi empat buah tungku perebusan yang terletak kedua sisi kanan kiri bangunan, empat buah tempat penyaringan dan penggumpalan yang terletak tidak jauh dari tungku perebusan, sebuah 
meja beton untuk meletakkan delapan buah cetakan tahu, dan satu buah alat penggiling yang lansung terhubung dengan ruang mesin.

\section{g. Pemilihan Jenis Teknologi dan Peralatan}

Peralatan yang digunakan oleh Usaha Tahu Mandiri sebagian besar masih bersifat semi tradisional. Teknologi yang digunakan antara lain mesin penggiling. Peralatan ini pertama kali dibeli oleh Bapak Suprianto dalam keadaan baru.Kemudian, tungku perebusan yang tebuat dari beton dibuat sendiri oleh Bapak Suprianto. Diatas tungku beton tersebut diletakan drum dengan diameter $58 \mathrm{~cm}$ yang digunakan sebagai wadah untuk merebus dan untuk proses pemotongan tahu menggunakan mistar. Selanjutnya adalah peralatan yang terbuat dari kayu dan kawat jaring. Bapak Suprianto memiliki satu toko langganan di Kota Galang untuk membeli peralatan baru jika peralatan lama sudah tidak dapat digunakan kembali seperti ember besar, ember timba, drum rebusan, kuali, selang, kain saring, kain, kompor gas, tirisan, sutil. Peralatan lain yang biasanya dibuat sendiri oleh Bapak Suprianto antara lain rak tahu, cetakan, centong, gayung.

\section{Aspek Manajemen dan Sumber Daya Manusia}

Usaha Tahu Mandiri merupakan usaha Perorangan.Pengrajin tahu menjalankan usahanya dengan tradisional.Hal ini membuat usaha dijalankan secara non formal dan belum memiliki struktur organisasi tetap.Pemegang kendali berada ditangan pemilik.Usaha Tahu Mandiri memiliki satu orang sebagai pemilik usaha dan delapan orang pekerjaan yang terdiri dari empat orang tenaga kerja dalam keluarga dan empat orang tenaga kerja luar keluarga.Sistem manajemennya bersifat close manajemen. Hal ini dapat dilihat dengan semua kegiatan ditentukan oleh pemilik.(Melayu \& Hasibuan, 2017).

\section{Aspek Finansial}

Analisis aspek finansial digunakan untuk menganalisis suatu usaha dari segi keuangan terdapat empat kriteria investasi, antara lain Net Present Value (NPV), Internal Rate of Return (IRR), Net B/C ratio, dan Payback Period (PP) (Kasmir \& Jakfar, 2003). Perhitungan dimulai dari awal tahun berdirinya Usaha Tahu Mandiri yaitu dari tahun 2008 hingga tahun 2013 dan tahun 2014 pada saat Usaha Tahu Mandiri melakukan ekspansi usahanya, baik dari segi produksi dan alat - alat yang digunakan dalam proses produksi hingga tahun 2018.

Tabel 2. Hasil Analisis Finansial Usaha Tahu Mandiri

\begin{tabular}{|c|c|c|c|}
\hline Kriteria & Indikator & & Hasil \\
\hline NPV 2008-2013 & $>0$ & $\mathrm{Rp}$ & 109.897 .985 \\
\hline IRR 2008-2013 & $>\mathrm{Df}$ & & 49,26 \\
\hline Net B/C 2008-2013 & $>1$ & & 2,02 \\
\hline PP 2008-2013 & $<$ Umur Usaha & \multicolumn{2}{|c|}{3 tahun 9 bulan 11 har } \\
\hline NPV 2014-2018 & $>0$ & $\mathrm{Rp}$ & $66.127 \cdot 532$ \\
\hline
\end{tabular}




\begin{tabular}{ccc}
\hline IRR 2014-2018 & $>$ Df & 34,06 \\
Net B/C 2014-2018 & $>$ 1 & 1,25 \\
PP 2014-2018 & $<$ Umur Usaha & 2 tahun 1o bulan 13 hari \\
\hline
\end{tabular}

\section{a. Net Present Value (NPV)}

Perhitungan NPV dilakukan untuk, mengetahui jumlah keuntungan bersih yang diperoleh selama periode usaha.Pada perhitungan PV yang dilakukan, jumlah PV negatif pada tahun 2008 - 2013sebesar Rp93.911.350 dan PV positif pada tahun 2014 - 2018 sebesar Rp 203.809.740. PV negatif diperoleh dari jumlah Net Benefit negatif pada tahun pertama dan ketujuh, karena jumlah keuntungan belum dapat menutupi jumlah biaya yang dikeluarkan. Sedangkan PV positifpada tahun 2008 -2013 yang diperoleh dari perhitungan adalah sebesar RpRp 265.554.741 dan PV postif pada tahun 2014 - 2018 yang dieroleh dari perhitungan adalah sebesar Rp 331.682.273. Pada penelitian ini Jumlah PV positif ini diperoleh dari penjumlahan Net Benefit yang positif yaitu pada tahun kedua sampai tahun keenam dan tahun kedelapan sampai tahun kesebelas umur usaha. Dari PV positif dan PV negatif pada tahun 2008 - 2013 akan didapatkan jumlah NPV sebesar (Rp 109.897.985) yang berarti bahwa Usaha Tahu Mandiri akan mendapatkan keuntungan bersih sebesar (Rp 109.897.985) dan pada tahun 2014 - 2018 PV positif yang diperoleh dari perhitungan adalah sebesar Rp 66.127.532Usaha Tahu Mandiri akan mendapatkan keuntungan bersih sebesar Rp 66.127.532.

\section{b. Internal Rate of Return (IRR)}

Perhitungan IRR suatu kelayakan dapat diketahui dengan membandingkan nilai IRR dengan nilai discount factor. Nilai discount factor yang digunakan sebesar 16 persen. Dari perhitungan diketahui bahwa Usaha Tahu Mandiri didapat nilai IRR pada tahun 2008 - 2013 sebesar 49,26\% dan pada tahun 2014 - 2018 sebesar 34,06\%.

\section{c. Net Benefit Cost Ratio (Net B/C)}

Pada perhitungan Net B/C dalam perhitungan kriteria investasi, diperoleh nilai Net B/C pada tahun 2008-2013 sebesar 2,02 dan Net B/C tahun 2014-2018 sebesar 1,25.

\section{d. Payback Period (PP)}

Perhitungan PP digunakan untuk melihat jangka waktu pengembalian modal pada Usaha Tahu Mandiri pada investasi pertama yaitu pada tahun 2008 - 2013 pengembalian modal usaha pada 3 tahun 9 bulan 11 hari dan pada tahun 2014 Usaha Tahu Mandiri melakukan ekspansi usahanya mulai dari kapasitas produksi, luas produksi, penambahan produk, dan luas pemasaran dengan PPnya terjadi pada 2 tahun 5 bulan 16 hari atau pada tahun ke 9 dari awal berdirinya Usaha Tahu Mandiri. Bila dibandingkan umur usaha yakni selama 11 tahun, maka jangka waktu pengembalian modal usaha lebih cepat dari umur usaha. 


\section{SIMPULAN}

Dari hasil analisis yang telah dilakukan pada Usaha Tahu Mandiri baik dari aspek finansial maupun aspek non finansial, maka dapat diambil beberapa kesimpulan, yaitu : 1) Berdasarkan analisis aspek non finansial, Usaha Tahu Mandiri dapat dikatakan belum layak, kecuali pada aspek pasar dan pemasaran, aspek teknis. Analisis aspek hukum dikatakan belum layak karena izin kepemilikkan tanah Usaha hanya memiliki Surat Penyerahan Penguasaan Tanah Dengan Cara Ganti Rugi dan surat tersebut berkekuatan hukum yang sangat lemah, aspek manajemen dikatakan kurang layak karena usaha tahu ini belum memiliki pencatatan finansial yang baik ataupun pembukuan atas penjualan yang dilakukan. Usaha ini juga belum memiliki struktur organisasi, Sedangkan analisis aspek lingkungan dikatakan kurang layak karena usaha ini membuang air limbah langsung ke kali terdekat tanpa memberikan perlakukan khusus. Pada jangka panjang, hal ini tentunya dapat menimbulkan gangguan berupa pencemaran lingkungan. 2) Analisis kelayakan finansial menunjukkan bahwa Usaha Tahu Mandiri ini layak untuk dijalankan. Hal ini dapat dilihat dari nilai NPV pada investasi pertama sebesar Rp. 109.897.985 dan nilai NPV pada investasi kedua Rp. 66.127.532, nilai IRR pada investasi pertama 49,26\% dan nilai IRR pada investasi kedua 34,06\%, nilai Net B/C pada investasi pertama 2,02 dan nilai Net B/C pada investasi kedua 1,25 serta nilai payback period investasi pertama 3tahun 9bulan 11 hari dan nilai payback period investasi kedua 2tahun 10 bulan 13 hari.

\section{DAFTAR PUSTAKA}

Anoraga, \& Sudantoko. (2002). Koperasi, Kewirausahaan, dan Usaha Kecil. Jakarta: Rineka Cipta.

Anzitha, S. (2019). ANALISIS PENDAPATAN USAHA PEMBUATAN TEMPE DENGAN TAHU DI KOTA LANGSA. JURNAL AGRICA, 12(2), 87-91.

Fitriani. (2017). Analisis Pengaruh Tenaga Kerja dan Bahan Baku Terhadap Nilai Produksi Industri Tahu Tempe 2008-2012 Di Makassar.Skripsi. Makassar: FAKULTAS EKONOMI DAN BISNIS ISLAMUNIVERSITAS ISLAM NEGERI (UIN) ALAUDDIN MAKASSAR.

Irwanto, R. (2011). Pengaruh Pembuangan Limbah Cair Industri Tahu Terhadap Kualitas Air Sumur Di Kelurahan Krobokan Kota Semarang.Skripsi. Semarang: Fakultas Ilmu Sosial UNNES.

Kasmir, \& Jakfar. (2003). Studi Kelayakan Bisnis. Jakarta: Kencana.

KLHH. (2014). Peraturan Menteri Lingkungan Hidup dan Kehutanan. Diunduh Tanggal dari JDIH Kementerian Lingkungan Hidup dan Kehutanan: http://jdih.menlhk.co.id/uploads/files/P_162019_BAKU_MUTU_AIR_LIMBAH_menlhk_07162019080451.pdf tanggal 15 November 2018

Melayu, \& Hasibuan. (2017). Manajemen Sumber Daya Manusia. Jakarta: Bumi Aksara.

Sholikhah, L. M. (2017). Peran Usaha Industri Kecil Tahu Terhadap Kondisi Sosial Ekonomi Masyarakat Desa Kalisari Kecamatan Cilongok Kabupaten Banyumas.Skripsi. Yogyakarta: Fakultas Ilmu Sosial UNY.

Soekartawi. (2001). Pengantar Agroindustri. Jakarta: PT. Raja Grafindo Persada.

Suliyanto. (2010). Studi Kelayakan Bisnis Pendekatan Praktis. Yogyakarta: ANDI Yogyakarta.

Sumarni, Murti, \& Soeprihanto, J. (2010). Pengantar Bisnis (Dasar-dasar Ekonomi Perusahaan). Edisi ke 5. Yogyakarta: Liberty Yogyakarta.

Syafa'at, I. (2016). Penataan Ulang Tata Letak Fasilitas Pabrik Tahu “Susukan” Desa Tamanrejo Kendal. Abdimas Unwahas, Vol. 1 No. 1. 